\title{
Understandings of the Transformation of Financial Management Mode in Enterprise Groups
}

\author{
Qiuping Ouyang*, Min Peng, Yuting Guo \\ Ji’an College, Ji’an City 343000, Jiangxi Province, China. E-mail: 524665401@qq.com
}

Abstract: Sharing economy has been promoted under the background of rapid social development. Meanwhile, financial management modes in enterprise groups have been transformed accordingly to make improvements in financial management, which brings critical impacts on investment decisions. Therefore, the transformation of financial management mode must be free from the traditional mode and should be conductive to the transformation development of financial management. Therefore, this article puts forward several understandings on the transformation of financial management mode for reference.

Keywords: Financial Management in Enterprise Groups; Transformation; Understandings

With the rapid development of science and technology and market economy, competitions among various industries are becoming increasingly fierce. All enterprises and institutions are undergoing transformation and upgrading, and turning into changing and innovating traditional financial management. In the process of transformation, the financial management presents a multi-dimensional mode, which is convenient for financial managers to conduct a comprehensive analysis, and to standardize and uniformly manage financial management to promote the development of enterprise financial management.

\section{Types of financial management mode}

\subsection{Traditional mode}

Under the traditional financial management mode, enterprises will set up their own financial department, recruit financial personnel and open special financial accounts for management. Financial personnel will first settle accounts separately, then the financial work will be managed by managers, and financial budget will be controlled. Instead of monitoring the specific situation of financial operation in real time, this method takes the way of reporting the superiors and then determines the implementation differences and budget targets. This method is greatly lagging. Financial managers need to set up separate funds to carry out fund management work, and manage them from the enterprise level. However, they still can't realize real-time scheduling and management, which leads to low using efficacy ${ }^{[1]}$.

\subsection{Financial shared service center}

Financial shared service is to give full play to the functions of company's financial accounting and other aspects, such as a large number of repetitive processing and centralized processing by using financial management information. In this way, scale effect can be achieved, repetitive application can be avoided, and the efficiency of enterprise financial management can be promoted and the operating costs of enterprises can be reduced. Currently, the financial shared ser-

Copyright (C) 2020 Qiuping Ouyang et al.

doi: $10.18282 /$ bam.v2i2.1377

This is an open-access article distributed under the terms of the Creative Commons Attribution Non-Commercial License

(http://creativecommons.org/licenses/by-nc/4.0/), which permits unrestricted non-commercial use, distribution, and reproduction in any medium, provided the original work is properly cited. 
vice is a new management mode for enterprises, which has been widely promoted both inside and outside many enterprises. As a relatively mature management mode, the financial shared service center uses modern information technology to build a shared management system, integrates financial data, and realizes financial data sharing at enterprise's level.

\subsection{Finance company}

Finance company is a non-financial institution, aiming to improve the ability of financial control and capital management of enterprises, and meanwhile help to improve the efficiency and quality of capital management. Finance company is run by independent legal entities and hold independent financial accounting to provide services for enterprises. As an independent legal entity, a finance company undertakes the internal and external work of enterprises and creates larger economic benefits. China has high requirements for the establishment of finance companies, and makes clear requirements in the field of registered capital, total assets and net assets income ${ }^{[2]}$.

\section{Suggestions on the transformation of financial management mode}

The establishment of financial management institutions can scientifically define the contents of financial management.

Firstly, it is necessary to strengthen the management of financial institutions. People regard the essence of financial management as accounting in the stage of socialist market economy. However, under the market economy, the management system of enterprises has been gradually established, and financial management has become a part of the financial work of enterprises. It is a functional activity of modern enterprises, which not only needs to deal with financial relations, but also needs to show the value movement of management. Accounting does not belong to functional management, but a comprehensive financial information service department. It plays a critical role in the modern enterprise support system. Therefore, the construction of modern financial management system should be divided into management department and accounting department. Both of the two departments should be ensured to perform their respective duties and work together ${ }^{[3]}$.

Secondly, it is necessary to redefine the content of financial management, and improve its quality on this basis. Many changes have taken place in the content of financial management currently, mainly from the previous transactional processing, capital raising, tax form evaluation, tax declaration, cost control, accounting control, budget control, internal audit, financial supervision, etc. It transforms the basic financial operation process, enterprise risk assessment, and operational analysis of added value, etc., to construct the performance management mode and strategic work of the whole enterprise. During this process, it is an important condition to first improve the basic financial process. The improvement of basic financial management process includes procurement, integrated supply chain information system and cost procurement control, etc., all of which need to ensure accuracy. Meanwhile, it is necessary to do well in assessing the business risks of enterprises. Risk assessment and business opportunities of enterprises refer to the growth lever of income in a great sense. Therefore, it is necessary to make sure the confirming, creating and maintaining work have been properly done. In the risk management of enterprises, financial personnel must participate extensively, and establish a process that can measure and control the risk. For example, in Microsoft, the risks of enterprises are regulated by an integrated committee. It uses the operation mode of internal risk consultation, and appoints risk managers in developments of operation, sales, and product research in enterprises. In corporate management, risk managers, being as a tool, aims at enhancing managers insight into future results and improving the company's ability to deal with related situations $^{[4]}$.

\section{Further strengthening the construction and quality management of fi- nancial personnel}

Financial personnel must have many core skills, including quantitative analysis skills, performance measurement skills, and information management skills. Constructions will then start within the specialized financial management 
department, and the organizational transformation ability and comprehensive information analysis ability will be upgraded. However, to better adapt to the needs of the modern market, financial personnel need to make some improvements in these aspects, including the market knowledge of products, the ability of leadership, the quality of individuals and the correlation between various links. The quality of individuals is very important. They should not only strengthen their own knowledge, but also communicate frequently with managers, procurement staff, customers, suppliers, and so on. In this way, they can fully grasp the relevant knowledge of the industry, the best procurement plan, relevant negotiation skills and communication skills. With such abilities in the future, financial personnel are able to measure the cost and benefit of the procurement process, and to work with department managers to formulate and improve the procurement process.

There will be more work contents for financial department in the future. So it is necessary to start the transformation of the whole business organization to solve many problems, including the definition of skills, personnel recruitment, training, performance measurement and personnel management, and so on.

\section{Construction of financial information system in enterprise groups}

Financial modernization of information technology is to promote the integration of enterprise financial and business management. In such method, fund management, supervision and control, risk avoidance can be provided with a more solid guarantee, and enterprise information management can be realized. When building enterprise financial information system, it is a major trend to use unified computer financial software to integrate financial information and business processes in the future, which is also the key to success. In this case, enterprises must take it as the breakthrough point. By starting with the problems that are needed to be solved, enterprises can take financial management as the main support, and strengthening the management of weak links. Meanwhile, enterprises can vigorously promote computer software technology, and realize the integration of finance and business. At the same time, they should strengthen supervision and management, do well in risk management and control, accelerate the turnover of funds, and improve the efficiency of the use of funds. In addition, it is necessary to plan and co-ordinate the development law and process of computer technology, and makes a practical implementation layout. Firstly, enterprises should to choose state-recognized financial management software to realize the comprehensive accounting computerization management, which needs to be managed as the basic work of accounting. Secondly, it is necessary to further promote the financial and business integration management, establish a unified management platform, use integrated management software, and solidify the effective rules and regulations of enterprises into the application management procedures. These are not only to realize the informationization and digitalization of sales, supply and production relations in the financial system, but also to realize data sharing and standardize and efficiently manage financial management, such as budget, settlement and monitoring. Thirdly, it is necessary to develop advanced ERP software, actively absorb advanced ideas and experiences both at home and abroad, reform the internal management mode of enterprises and optimize and adjust the production structure of enterprises. Moreover, it is also helpful to combine all internal production, supplier resources and user needs to promote enterprises to achieve comprehensive information management.

\section{References}

1. Hu G. The transformation of enterprise financial management under the sharing economy model (in Chinese). China Collective Economy 2020; (17): 143-144.

2. Peng $H$. Research on financial management transformation of state-owned enterprises under financial sharing mode (in Chinese). Undertaking \& Investment 2020 (7): 59-60.

3. Qu L. Thinking about the transformation path of enterprise financial management under the financial sharing mode (in Chinese). China Circulation Economy 2020; (17): 62-63.

4. Zhang S. On the design of financial management mode of state-owned enterprises-based on financial sharing center (in Chinese). Businessman 2020; 34(16): 150-151. 


\section{About the author}

Qiuping Ouyang (1986.10.03), female, Han nationality, was born in Ji'an, Jiangxi Province in China. She is a teaching assistant and holds a bachelor's degree in accounting. She works in Ji'an College and her research interest is transformation of financial management of companies.

Min Peng (1988.10.19), female, Han nationality, was born in Ji'an, Jiangxi Province in China. She is a teaching assistant and holds a master's degree in accounting. She works in Ji' an College and her research interests are accounting and economic management.

Yuting Guo (1989-), female, Han nationality, was born in Ji'an, Jiangxi Province in China. She holds CPA license, and a bachelor's degree in management. She works in Ji'an College and her research interests are accounting and auditing. 